\title{
Perencanaan Jalur Sepeda Sebagai Tujuan Wisata Desa Di Kecamatan Payangan, Kabupaten Gianyar
}

\author{
IDA BAGUS SURYA MAHAYANA ${ }^{1}$, IDA AYU MAYUN²*, \\ ANAK AGUNG MADE ASTININGSIH² \\ 1Program Studi Agroekoteknologi Program Reguler Sore Fakultas Pertanian \\ Universitas Udayana \\ 2 Program Studi Agroekoteknologi Fakultas Pertanian Universitas Udayana \\ *E-mail: dayumayun12@gmail.com
}

\section{ABSTRACT \\ Bike Path Planning as a Tourist Destination Village in the District of Gianyar Payangan Regency}

Payangan District has potential good attractiveness to the develope. Some of a district in the villages, dont have tourism accomodation yet. Developed alternative is cycling. This cycle way is needed to optimalize all the potential tourism industry in the villages. This cycle way concept is doing by approach and concideing of potential wich has been existing in order to creased tourism industry. Does cycle way are present 1) potential in each village, 2) the passing way each village, 3) tourism industry, 4) group of tourism, 5) tourism production, 6) a circulation concept.

Keywords : lanscape plan, payangan district, group tourism, potential in each village, cycle way plan

\section{Pendahuluan}

Kecamatan Payangan memiliki potensi dan daya tarik yang tinggi untuk dikembangkan sebagai daerah tujuan wisata. Bentang alam dengan lembah-lembah sungai serta hamparan persawahan yang berteras menciptakan pemandangan yang indah dan alami. Suasana lingkungan tenang dan nyaman menciptakan pemandangan yang menyejukkan hati.Kecamatan Payangan memiliki potensi dan daya tarik yang tinggi untuk dikembangkan sebagai daerah tujuan wisata. Bentang alam dengan lembah-lembah sungai serta hamparan persawahan yang berteras menciptakan pemandangan yang indah dan alami. Ditambah oleh suasana lingkungan tenang dan nyaman menciptakan pemandangan yang menyejukkan hati.

Kehidupan masyarakat Payangan masih kental dengan adat dan budaya, dimana pada saat perayaan-perayaan tertentu, seperti upacara di pura-pura sering dipentaskan berbagai kesenian dari masyarakat setempat maupun dari desa lainnya. Desa Bukian dan Desa Puhu belum terdapat sarana pariwisata, namun disana banyak terdapat pengrajin 
yang membuat berbagai barang seni untuk keperluan wisatawan. Menikmati panorama alam dan seni kerajinan di desa-desa tersebut diperlukan sebuah alternatif wisata. Alternatif wisata yang dikembangkan yaitu wisata sepeda bagi wisatawan.

Perencanaan jalur sepeda ini sangat diperlukan untuk mengoptimalkan seluruh potensi wisata di desa-desa tersebut. Sehingga permasalahan yang dapat dirumuskan dari penelitian ini adalah adanya potensi dan kendala wisata yang terdapat di beberapa desa di Kecamatan Payangan dan melihat bagaimana konsep perencanaan jalur wisata yang cocok dikembangkan di desa tersebut. Setelah dapat merumuskan permasalahan seperti yang disampaikan sebelumnya maka rumusan tujuan dari penelitian ini yaitu untuk dapat mengidentifikasi dan menganalisis potensi dan kendala yang terdapat di Kecamatan Payangan sehingga dapat dijadikan tujuan wisata dan membuat suatu konsep perencanaan jalur sepeda yang melalui desa-desa di Kecamatan Payangan. Kemudian manfaat yang diperoleh dari penelitian perencanaan jalur sepeda di Kecamatan Payangan, Gianyar ini adalah pertama adalah untuk menggali potensi yang terdapat di Kecamatan Payangan, kedua adalah mengetahui wisata penunjang yang cocok dilakukan untuk kegiatan bersepeda di Kecamatan Payangan, ketiga adalah untuk bahan pertimbangan Kecamatan Payangan menjadi daya tarik baru bagi para wisatawan, dan keempat untuk membuka lapangan kerja baru dan menambah pendapatan masyarakat khususnya di Kecamatan Payangan.

\section{Metode}

\subsection{Waktu dan Lokasi Penelitian}

Lokasi penelitian dilakukan di Kecamatan Payangan. Lokasi hanya dibatasi pada Desa Bukian, Puhu, Kerta, dan Melinggih. Pemilihan lokasi dengan pertimbangan-pertimbangan, antara lain desa-desa tersebut mempunyai kawasan yang potensial untuk dijadikan tempat wisata, khususnya bersepeda. Mempunyai panorama yang indah dan hawa yang sejuk, di desa ini banyak produk wisata yang belum dikenal wisatawan. Penelitian dilakukan dari bulan November 2013-Januari 2014.

\subsection{Alat dan Bahan}

Alat yang digunakan dalam penelitian studi perencanaan ini meliputi kamera digital, GPS, serta komputerisasi. Bahan yang digunakan dalam penelitian ini meliputi pensil, bolpoin, kertas.

\subsection{Metode Penelitian}

Metode yang digunakan dalam penelitian ini adalah metode analisis deskriptif dan kualitatif, menggunakan metode Simonds (2006).

\section{Hasil dan Pembahasan}

\subsection{Sasaran Perencanaan Jalur Wisata Sepeda}

Perencanaan jalur sepeda di Kecamatan Payangan adalah upaya untuk mengangkat potensi setiap desa yang berada di Kecamatan Payangan, serta menjadikan Kecamatan 
Payangan sebagai tujuan wisata, baik agro maupun wisata olahraga, dan juga sebagai proses keputusan jangka panjang untuk menjadikan Kecamatan Payangan sebagai tujuan wisata yang berkembang kedepannya.

\subsection{Analisis dan sintesis}

Dari perencanaan jalur sepeda yang akan di buatterdapat potensi yang ada di tiap desa yang akan ditonjolkan, dan ada pula beberapa kendala yang harus diperbaiki. Berikut adalah tabel analisis potensi dan sintesis kendala setiap spot pemberhentianatau tiapdesa

\subsection{Pengolahan Hasil Studi}

\subsubsection{Biofisik}

Secara biofisik Kecamatan Payangan mempunyai potensi berupa Sungai Ayung, pengrajin patung, perkebunan, makam batu, perkebunan, sarkopagus, dan pemandangan lembah yang sangat indah. Tetapi untuk saat ini di Kecamatan Payangan belum mempunyai solusi untuk mengangkat potensi-potensi tersebut, sehingga perlu adanya suatu perencanaan yang bisa mengangkat potensi yang terdapat di Kecamtan Payangan sebagai daerah wisata. Perencanaan ini juga dapat meningkatkan kesejahteraan manusia yang berada di setiap desa.

Kecamatan Payangan dekat dengan Kecamatan Ubud sehingga sangat mudah untuk para wisatawan mencapainya. Di samping itu lokasi dekat dengan akses utama. Kendala yaitu belum adanya trasportasi khusus menuju. Keadaan demikian menjadi kurang nyaman bagi para wisatawan untuk mencapai tapak. Solusi untuk kendala tersebut adalah dengan menyediakan alat transportasi khusus untuk mencapai start point. Topografi Kecamatan Payangan tidak datar mempunyai jalan menanjak dan menurun sehingga dari topografinya yang menantang Kecamatan Payangan sangat baik untuk wisata sepeda. Kendala dari jalur ini adalah terdapat jalan curam dan licin pada saat turun hujan, karena tidak semua jalur menggunakan aspal atau hotmik, dan keadaan struktur tanah juga sangat labil sehingga mudah longsor. Solusi dari keadaan tersebut adalah membagi jalan tersebut menjadi beberapa zona yaitu zona bahaya atau menantang dan zona aman.

Iklim di Kecamatan Payangan sangat sejuk dan tergolong nyaman untuk melakukan aktifitas olahraga khususnya bersepeda, suasana yang sejuk bisa menambah semangat untuk berolah raga dan menjernihkan pikiran. Kendala dari iklim di payangan adalah kelembaban yang tinggi, hal itu menjadikan keadaan kurang nyaman bagi para wisatawan. Solusi dari kendala ini adalah memperbaiki saluran drainase untuk menghindari banjir, memperluas selokan dan memperdalam selokan.

Visual yang terdapat di payanagan sangat baik atau pemandangannya sangat indah dan di Kecamatan Payangan masih banyak areal persawahan dan perkebunan yang masih hijau dan itu bisa bermanfaat untuk menenangkan pikiran. Kendalanya adalah masih banyak terdapat areal yangbelum tertata. Solusinya adalah penataan pada tapak yang belum tertata dan menambahkan vegetasi agar menimbulkan kesan rapi. 


\subsubsection{Fasilitas}

Bangunan di areal tapak atau jalur wisata sepeda sebagian bangunan masih terlihat baik dan tertata. Kendalanya adalah sebagian dari bangunan belum terlihat baik karena belum tertata sehingga menimbulkan kesan kurang rapi. Solusinya adalah bangunan yang sudah baik tetap dipertahankan sedangkan bangunan yang kurang baik agar lebih diperhatikan dan diperbaiki dan menambahkan fasilitas yang diperlukan di setiap spot.

Area parkir khusus untuk wisatawan belum terdapat di areal ini. Solusinya adalah membangun areal parkir untuk para wisatawan yang berkunjung dan menambahkan garis parkir pada start poin. Tempat parkir sepeda belum tersedia di setiap spot pemberhentian. Solusinya adalah membuat tempat parkir sepeda di setiap spot, sehingga saat wisatawan berhenti di setiap spot, sepeda dapat parkir dengan baik dan terlihat rapi. Jalur sepeda ini belum terdapat rambu-rambu dan solusinya adalah disediakannya rambu-rambu di areal tapak atau jalur sepeda agar wisatawan waspada akan jalur yang mereka tempuh. Papan pengumuman belum ada pada setiap spot atau jalur sepeda, solusinya adalah menyediakan papan pengumuman agar wisatawan tau larangan atau mereka tahu dimana sedang berada. Setiap desa di Kecamatan Payangan masih banyak masyarakat belum mempunyai pekerjaan tetap, kendalanya adalah masyarakatnya belum terlatih. Solusinya adalah melibatkan masyarakat dalam wisata sepeda dengan menjadikan mereka sebagai pemandu wisata dan mendatangkan pelatih yang profesional.

\subsubsection{Sosial}

Banyak terdapat pengerajin dan petani di areal yang akan dijadikan sebagai jalur sepeda. Kendalanya adalah pengrajin dan yang terdapat di payangan dan petani belum dimanfaatkan dengan maksimal. Solusinya adalah melibatkan masyarakat sebagai pelaku wisata di setiap desa dan menjadikan wiasata sepeda sebagai sarana untuk merubah tarap hidup masyarakat agar menjadi lebih baik.

Budaya di tiap desa di Kecamatan Payangan mempunyai adat istiadat yang sangat kental dan masih banyak kegiatan agama yang dilakukan di lintasan jalur sepeda. Kendalanya adalah karena kegiatan jalur sepeda ini mempunyai spot tempat suci atau kegiatan keagamaan, jadi terdapat larangan bagi wanita yang berhalangan untuk memasuki tempat suci. Solusinya memberikan pengarahan bagi para wisatawan yang khususnya wanita yang sedang berhalangan dan untuk kegiatan keagamaan diakomodasikan dengan baik sehingga wisatawan antusias ingin mengenal tentang Kebudayaan Bali, adat istiadat, dan kegiatan keagamaan di bali, dan menyediakan jadwal kegiatan bagi para wiatawan.

\subsection{Konsep Perencanaan}

\subsubsection{Konsep Dasar}

Konsep dasar dari pengembangan jalur sepeda adalah cara untuk mengangkat potensi wisata yang terdapat di kecamatan payangan disamping untuk meningkatkan sumber daya manusia di tiap tiap-tiap desa yang akan dijadikan dan dilalui oleh jalur sepeda. Perencanaan ini dilakukan dengan pendekatan-pendekatan serta 
mempertimbangkan potensi yang sudah ada agar bisa lebih ditingkatkan sebagai daerah wisata dan meningkatkan sumber daya manusia khususnya dibidang pertanian, perkebunan, dan kerajinan tangan. Pendekatan sosial dilakukan untuk memberikan ruang sosial yang bertujuan untuk membangun emosional antara pelaku wisata sehingga terjalin hubungan yang harmonis, pendekatan nilai budaya juga dilakukan dengan mempertegas karakter di setiap desa yang digunakan sebagai jalur sepeda, dan melestarikan budaya yang dapat memberikan wawasan secara spiritual dan kenyamanan bagi para wisatawan.

\subsubsection{Konsep Ruang}

Konsep ruang terbagi atas ruang wisata alam dan ruang wisata sejarah budaya. Ruang wsata alam meliputi sawah, kebun tanaman langka, kebun bambu, dan penangkaran hewan. Ruang wisata sejarah budaya meliputi pengrajin patung, minuman tradisional, kubur batu, dan pura. Dalam pembagia nruang ini wisatawan akan diajak lebih mengenal potensi yang terdapat di tiap desa yang akan dilewati.

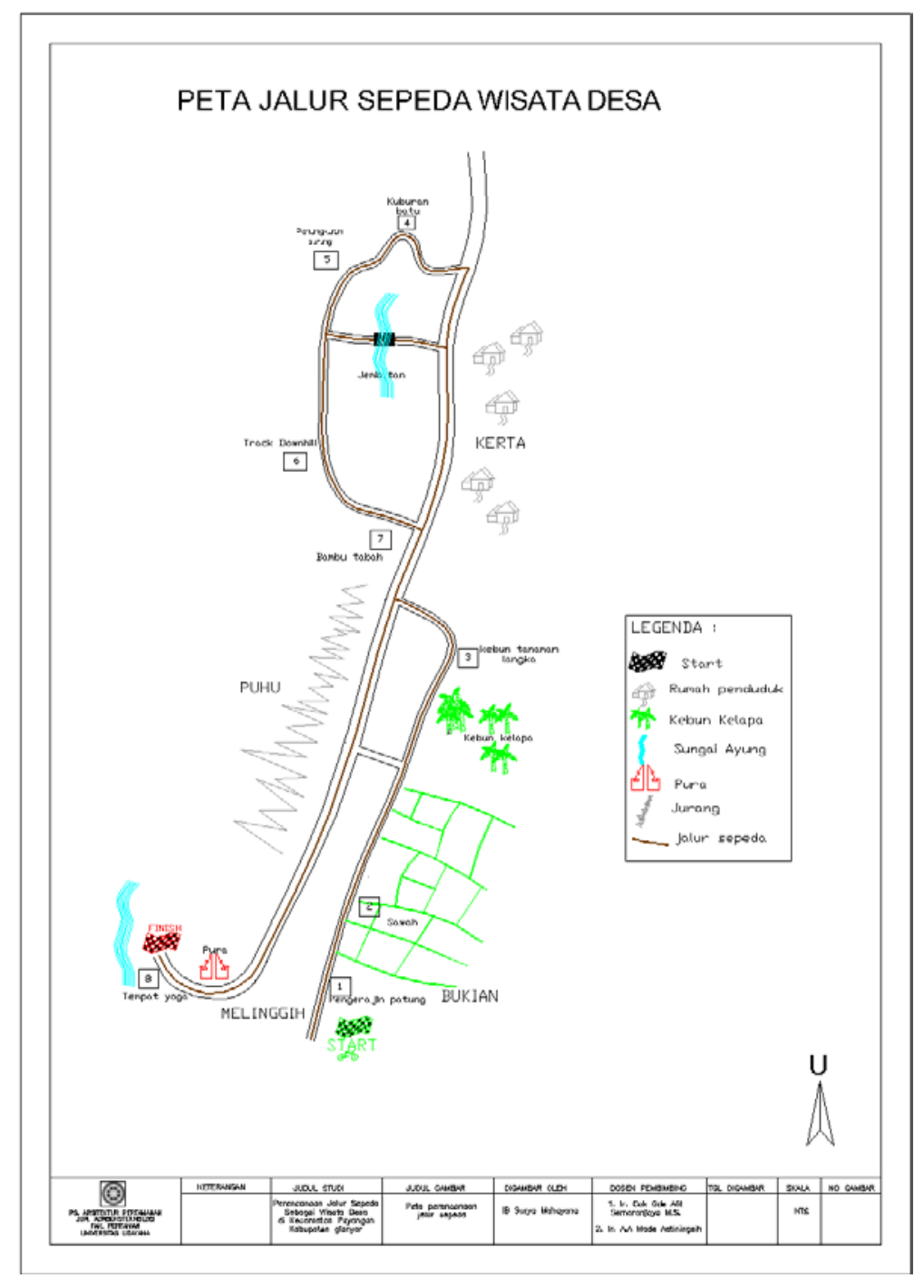

Gambar 1. Peta Jalur Wisata Desa 


\subsubsection{Konsep Sirkulasi}

Sirkulasi menghubungkan secara langsung dari ruang wisata alam menuju ruang wisata sejarah budaya. Sirkulasi menghubungkan semua titik pemberhentian diurut berdasarkan jarak terdekat dari Desa Bukian (sebagai titik start). Desa Bukian merupakan lokasi sangat sesuai untuk titik start, karena memenuhi criteria sebagai welcome area (area selamat datang). Desa Bukian adalah desa yang paling dekat dengan jalan raya dan mempunyai lahan yang cukup luas untuk dijadikan parkir.

\subsubsection{Rencana Jalur Wisata Desa}

Menikmati panorama alam dan seni kerajinan di desa-desa tersebut diperlukan sebuah alternatif wisata. Dari pemaparan diatas menunjukkan adanya keharmonisan antara masyarakat dengan alam dan adanya keharmonisan manusia dengan manusia lain, hal ini ditunjukkan dengan bersatunya masyarakat ditiap desa untuk menjaga warisan budaya peninggalan nenek moyang terdahulu.

\subsubsection{Kelompok Wisata Rekreasi}

Kelompok wisata yang pertama adalah wisata rekreasi, dimana wisatawan yang bersepeda dengan keluarga bisa bersepeda sambil menikmati produk wisata yang berupa pengrajin patung, titik berikutnya adalah hamparan sawah yang luas dan para wisatawan yang melewati areal ini bisa menikmati pemandangan sawah yang indah dan udara yang sejuk, dan pada musim tanam para wisatan bisa ikut bersama para petani untuk menanam padi dan melihat proses penanamannya dan pada musim panen para wisatawan yang bersama keluarga bisa ikut memanen padi dengan para petani. Pada titik berikutnya akan diajak berhenti dan istrahat sejenak di spot minuman tradisional. Wisatawan bisa melepas dahaga dengan meminum minuman tradisional dan untuk wisatawan yang masih anak atau yang tidak inginmencicipi tuak, disediakan juga kelapa muda dan minuman segar lainnya. Titik berikutnya adalah titik wisata perkebunan tanaman langka dimana di kebun tersebut terdapat tanaman buah - buahan bali asli yang akhir - akhir ini pemanfaatannya sudah jarang,baik itu dikonsumsi maupun untuk diperjual belikan, selanjutnya spot bambu tabah,dilanjutkan dengan kubur batu kono, dan yang terakhir adalah titik wisata penangkaran satwa liar disini wisatawanakandiajakberhentiuntukmelihatjenissatwa yang terdapat di penangkaranhewanini, danbisajugaberibteraksidenganhewan yang terdapat di penangkaranini.

\subsubsection{Kelompok Wisata Olahraga}

Kelompokwisatakedua adalah wisata sport atau olahraga dimana pada zona ini para wisatawan bisa menikmati jalurmenantangataudownhill, wisatawan akan diajak melewati jalan naik, turunan tajam, berkelak kelok dan berbatu, disinilah tantangan bagi para wisatawan yang gemar dengan olahraga yang cukup menantang, disamping jalan yang cukup menantang wisatawan juga dapat menikmati pemandangan lembah, terasiring sawah, dan menikmati udara yang sejuk. 


\subsubsection{Kelompok Wisata Religius}

Kelompok wisata terakhir adalah wisata religius dimanazona ini terdapat pada pemberhentian terakhir, disini para pengendara sepeda dapat melihat Pura Penataran Air Jeruk, dan mendengar informasi mengenai mitos berdirinya Pura Penataran Air Jeruk, wisatawan yang ingin menenangkan pikiran bisa melakukan yoga dpinggir sungai ayung dan difinish wisatawan akan diajak menikmati makanan yang tersedia, makanan yang menjadi ciri khas Desa Melinggih, yaitu be tutu. Di akhir perjalan ini wisatawan juga bisa menikmati suguhan yang tadi terdapat di seputaran jalur yang telah dilewati yaitu minuman tradisional ( tuak ), buah - buahan khas Bali.

\subsubsection{Pemaparan Rentang Waktu dan Jarak Tempuh Setiap Spot}

Dari pemaparan obyek dan kelompok wisata diatas maka jarak spot satu dan yang lainnya mempunyai jarak yang berbeda. Dari start menuju spot berjarak kira - kira $1 \mathrm{~km}$, jarak antara spot pertama menuju spot kedua berjarak $1 \mathrm{~km}$, spot kedua menuju spot ketiga $2 \mathrm{~km}$, jarak dari spot ketiga menuju spot keempat $2 \mathrm{~km}$, spot keempat menuju spot kelima berjarak $1 \mathrm{~km}$, spot kelima menuju keenam berjarak $5 \mathrm{~km}$, spot keenam menuju spot ketujuh $2 \mathrm{~km}$, dan spot ketujuh menuju down hill berjarak $2 \mathrm{~km}$, dan dari down hill menuju spot pura sekaligus finish berjarak $15 \mathrm{~km}$. Para wisatawan diberikan waktu disetiap spot pemberhentian kira - kira 20-35 menit. Para wisatawan menghabiskan waktu untuk menelusuri jalur ini berbeda - beda juga tergantung kelompok wisata mana yang ingin dipilih oleh wisatawan. Bila wisatawan ingin melakukan wisata religius yaitu pura dan yoga waktu tempuh relatif paling singkat, karena jarak yang ditempuh pendek dan spot yang ditemui sedikit dan wisatawan banyak menghabiskan waktu untuk beryoga. Wisatawan yang ingin melakuakan wisata keluarga mempunyai waktu sedang karena spot yang dilewati yaitu pengerajin patung, sawah, minuman tradisional, kebun tanaman langka, bambu tabah, kuburan batu, dan penangkaran satawa liar. Dan yang terakhir apabila wisatawan ingin melakukan wisata olahraga, disini wisatawan akan menghabiskan waktu paling lama, karena akan melewati keseluruhan dari spot dan melawati jalur yang menantang, jalur naik turun berbatu dan berpasir. Dari keseluruhan jalur sepeda yang ditempuh oleh wisatawan mulai dari start sampai finish menempuh sekitar kira - kira 30km. Total waktu yang dihabiskan untuk melalui jalur wisata sepeda ini kira - kira 2 - 3 jam.

\subsection{Objek Wisata}

\subsubsection{Objek Wisata Pengerajin Patung}

Objek yang pertama adalah pengerajin patung, para wisatawan dapat menikmati produk wisata yang terdapat di Desa Bukian yang kebanyakan penduduknya berprofesi sebagai pengerajin patung.

\subsubsection{Objek Wisata Areal Persawahan}

Objek pemberhentian kedua adalah areal persawahan para wisatawan yang bersepeda dapat menikmati pemandangan hamparan sawah yang luas dan wisatawan juga akan diajak untuk melihat petani melakukan aktifitas disawah apabila pada musim 
panen para wisatawan akan diajak berinteraksi dengan petani untuk ikut memanen padi, dan bila pada masa tanam para wisatawan akan diajak untuk menanam padi.

\subsubsection{Objek Wisata Pembuatan Minuman Tradisional}

Objek ketiga adalah spot dimana para wisatawan akan diajak untuk melihat pembuatan minuman tradisional, penduduk memanfaatkan kelapa sebagai minuman tradisional (tuak). Para wisatan bisa mencicipi minuman tradisional tersebut tetapi dianjurkan hanya satu gelas saja karena tuak minuman yangmengandung alkohol.

\subsubsection{Objek Wisata Perkebunan Tanaman Langka}

Objek yang keempat adalah spot tanaman langka, spot tanaman yang dimaksud disini adalah tanaman yang sudah hampir tidak pernah dipakai untuk sesajen khususnya di bali, adapun buah - buah yang dimaksud adalah, ceroring, kepundung, badung, sentul, dll. Wisatawan akan diajak melihat buah asli bali yang hampir jarang keberadaanya di pasaran, dan wisatawan juga bisa mencicipi buah yang terdapat di perkebunan ini

\subsubsection{Objek Wisata Perkebunan Bambu Tabah}

Objek kelima adalah perkebunan bambu tabah, para wisatan akan diajak berkeliling di areal perkebunan sejuk yang dikelilingi bambu, dan mendengar penjelasan mengenai fungsi dari bambu tabah dan manfaat dari rebung bambu tabah yang bisa dipakai sebagai sayuran yang bervitamin, disamping pemanfaatan bambu sebagai kerajinan

\subsubsection{Objek Wisata Kubur Batu Kuno}

Objek keenam adalah spot dimana wisatawan akan diajak melihat makam batu kuno. Dimana makam ini ditemukan pada tahun 1973 dibawah pohon nangka oleh masyarakat.Pada saat ditemukan Sarkofagus ini, masih ditemukan mayat yang memakai mahkota dari perunggu, selempang, dan juga memakai cincin.

\subsubsection{Objek Wisata Penangkaran Satwa Liar}

Objek ketujuh adalahpenangkaran satwa liar, wisatawan akana diajak melihat satwa yang dipelihara di areal ini, wisatawan bisa melihat beberapa jenis burung, monyet, dan kijang. Masyarakat sekitar ingin menjadikan areal ini sebagai penangkaran hewan liar, karena hewan - hewan khususnya monyet dan kijang kerap mengganggu tanaman masyarakat.Objek wisata perkebunan tanaman langka, bambu tabah

\subsubsection{Objek Wisata Religius (Pura dan Tempat Yoga)}

Objek terakhir adalah spot religius dimana di jalur yang dilewati wisatawan terdapat pura, pura ini dinamakan Pura Penataran Er Jeruk, disini wisatawan dapat medengarkan bagaimana sejarah berdirinya pura ini. Spot terakhir juga terdapat sarana yoga, bagi wisatawan yang beryoga spot pemberhentian terakhir ini sangat cocok karena tempatnya dipinggir sungai ayung menambah suasana yg sejuk dan menenangkan. 


\section{Simpulan Dan Saran}

\subsection{Simpulan}

Simpulan dari penelitian ini adalah potensi kecamatan payangan untuk dikembangkan sebagai daerah wisata, karena banyak berbagai macam tempat wisata yang dapat diangkat di kecamatan ini, yang paling menonjol adalah wisata agro, karena payangan mempunyai hawa yang sejuk dan pemandangan yang masih alami. Sedangkan konsep dari perencanaan jalur sepeda dikecamnatan payangan adalah agar potensi wisata di kecamatan payangan bisa dipublikasikan dan tarap hidup masyarakat yang terdapat di kecamatan payangan dapat terangkat dari segi ekonomi, karena banyak wisatawan yang belum tahu produk wisata yang terdapatdi Kecamatan Payangan.

\subsection{Saran}

Saran yang bisa diberikan adalah bahwa hasil penelitian perencanaan jalur sepeda ini dapat dilanjutkan pada tahap pengembangan desain atau perancangan pada setiap desa yang berpotensi sebagai jalur wisata. Selain itu juga dapat digunakan sebagai masukan dan bahan pertimbangan bagi pelaku wisata sebagai alternative pengembangan jalur wisata di setiap desa yang mempunyai potensi. Tahap perancangan sebaiknya memperhatikan dan mempertimbangkan aspek budaya (adat istiadat) dan potensi yang terdapat di setiap desa.

\section{Daftar Pustaka}

Knudson, D.M. 1980. Outdoor Recreation. Mac Millan Publishing Co., Inc. London

Marsh, W. M. 2005. Lanscape Planning, John Wiley and Sons, Inc. United States of America

Syatauw, C. Fajarsari, E J. Apriyadi, F. PerancanganJalurKhususSepedaPadaJalan Ahmad Yani Surabaya SebagaiBentukRevitalisasiKendaraanTidakBermotor. UniversitasGunadarma. Jakarta 